Państwowy Białoruski Uniwersytet Kultury i Sztuki

Mińsk

https://orcid.org/0000-0002-1783-9596

\title{
Ценные предметы в памятниках белорусской литературы XVI-XVII веков
}

Художественная ценность артефактов, описанных в белорусской литературе XVI-XVII веков (летописях, философско-богословских трактатах, переводной и полемической литературе, проповедях, дневниках и книжной поэзии), до сих пор не изучалась. Поэтому це ль ю данного исследования является характеристика художественного контекста ченных предметов, описанньх в известных памятниках белорусской литературы этого периода с позичий искусствоведения и антикварного дела.

Литературовед И. Саверченко в самом начале одной из своих монографий справедливо отмечает:

Белорусская народность, занимавшая в древний период (IX-XII века) просторы крупнейших восточнославянских княжеств - Полоцкого, Смоленского и Турово-Пинского, - в результате экономического и социально-политического развития, а также под натиском завоевателей с Востока и Запада в XIII-XIV веков консолидировалась вокруг своего нового государственного образования - Великого Княжества Литовского, Русского и Жамойцкого, которое со временем стало мощным европейским государством. Хотя пределы государства достигали Балтийского и Черного морей, его ядром оставались белорусские земли и белорусский этнос ${ }^{1}$.

1 I. Саверчанка, Старажытная паэзія Беларусі XVI- першая палова XVII cm., Мінск 1992, с. 4. 
Специалисты, изучающие материальные ценности белорусского народа, пришли к выводу, что одной из важнейших причин развития местной экономики и искусств на рубеже XIV и XV столетий стало перанаправление торговых путей Евразии в предшествующих XII-XIII веках: Поскольку пиратство в Средиземном море в те времена практически парализовало морскую торговлю между Западом и Востоком, реки и дороги на белорусских землях стали мошными торговыми артериями Европь, а княжества и их жители быстро богатели благодаря тому, что через их территории проходили крупнейшие в то время торговые пути ${ }^{2}$.

Таким образом, XIV и XV столетия оказались периодом мощного импульса в общем развитии искусств и культуры белорусских земель. Обусловили данный импульс следующие факторы: во-первых, как уже отмечалось, перенаправление евразийских торговых путей; во-вторых, интеллектуальная роль белорусов-литвинов в новом государственном образовании в центре Европы (делопроизводство в Великом Княжестве Литовском, Русском и Жамойцком долго велось на старобелорусском языке); в-третьих, смена Средневековья Ренессансом.

Эпоха Ренессанса, которая началась в Беларуси с деятельности (...) Франциска Скорины, очертила радикальные изменения в области культуры. В это время (...) получает распространение книгопечатание, увеличивается количество библиотек, открываются различные учебные заведения, возрождается интерес к истории, развивается наука (...) создаются шедевры живописи и архитектуры. Во всех направлениях идет накопление материальных и духовных ценностей ${ }^{3}$.

В самом полном названии Княжества присутствуют отсылки к его поликультурности: под Жамойтией понимали сегодняших литовцев (чьё искусство и культура имели балтскую, относительно изолированную от славян доминанту), под Русью - украинцев, а под Литвой белорусов (славяноязычность украинцев и белорусов всегда указывала на их связи с соседними славянскими народами - русскими и поляками). В связи с этим оправданным видится высказанное в свое время мнение И. Саверченки, ныне отражающее, впрочем, взгляд почти всего белорусского литературоведения на эту проблему:

\footnotetext{
2 Г. Барвенава, Тэкстыль Сярэднявечча на землях Беларусі, Мінск 2008, с. 8.

3 I. Саверчанка, Старажьтная паэзія Беларусі XVI- першая палова XVII ст., c. 7 .
} 
Историческая судьба белорусской литературы сложилась так, что в течение длительного периода она развивалась в (...) единстве с литературами Украины и Польши. Земли, находившиеся в (...) объединении, не могли не рождать художников, поэтов, философов, чье творчество было связано с судьбой трёх народов (...) Включение в контекст белорусской литературы творчества поэтов-уроженцев Беларуси, которые писали не только на белорусском (...) - это, на наш взгляд, наиболее правильный (...) подход к пониманию реальных исторически-литературных процессов, происходивших в Беларуси ${ }^{4}$.

В белорусской литературе раннего Средневековья, в явно подчинённых православной эстетике литературы Древней Руси поучениях или «Словах» Кирилла Туровского упоминания о ценностях довольно аскетичны: ...пленица златы, растворень жньньчюгомь, с многоипньньмм каменьемь ${ }^{5},-$ в них золото, жемчуг и драгоценные камни приводятся только как метафоры духовных ценностей христианства, сфера же искусства, а также её носителей и артефактов представлена как пастьри свиряюще $e^{6}$ - её символизируют пастухи-исполнители на флейтовых духовых музыкальных инструментах свирелях.

Показательно, что одни из первых не метафорических, а реальных ценностей, упоминаемые в раннеренессансной, ещё созданной на латинском языке, но уже белорусской по тематике и эстетике литературе Великого Княжества Литовского - в «Песне про зубра» Николая Гусовского, - это антикварные для того времени рукописи, написанные средневековой кириллицей за несколько столетий до появления ренессансной поэмы. В русском переводе поэмы Н. Гусовского это грам⿻аты русские, написанные греческой буквой․ Речь идёт явно о старинных кириллических рукописных книгах местного происхождения на церковнославянском языке, с которыми (как с очень ценными антикварными памятниками уже для того времени) были знакомы литераторы-белорусы рубежа XV-XVI веков. K данным книгам патриотически настроенный Н. Гусовский эмоционально апеллирует, а также оценивает их наряду с памятниками античной (древнегреческой и древнеримской) литературы. Кроме антикварных рукописей в качестве ценностей Н. Гусовским упоминаются: блеск одеяний... отливь

4 Там же, с. 8.

5 Хрэстаматьля па старажьтнай беларускай літаратурь, склад А. Коршунай, Мінск 1959, с. 26.

6 Там же, с. 24.

7 М. Гусойскі, Песня пра зубра, Мінск 1980 , с. 7. 
золототканых узоров на белом и красном, - богатый текстиль, а также «рога»9 - амбушурные духовые музыкальные охотничьи инструменты для охоты на зубра. В то время последние обычно инкрустировались драгоценными металлами.

Значительная часть ренессансной и борочной белорусской литературы - это книжная поэзия, написанная кириллицей на белорусском языке, созданная уже после легендарной поэмы Н. Гусовского. Наиболее развёрнуто давняя книжная поэзия земель Беларуси представлена

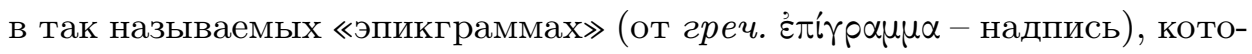
рыми местные литераторы эпохи Ренессанса надписывали и комментировали геральдические символы (гербы) своих магнатов-покровителей и родных городов. Данные эпикграммы активно публиковались на землях Беларуси в XVI-XVII столетиях.

Сама геральдика как знаковая система на уровне своих базовых символов включает ряд художественных изображений весьма ценных предметов (корон, скипетров, держав, инкрустированных доспехов и вооружения, перстней с драгоценными камнями), а также экзотических для наших широт видов животных (львов, оперений страуса, павлина либо фазана) и растений (лилий, пальм) и т. д. Все эти предметы повсеместно в Европе имели в то время немалую рыночную цену, а в отдельных европейских регионах, в том числе на территории Великого Княжества Литовского, оттенялись чертами, характерными для местного искусства, а также культурных традиций живущих тут народов.

Надписи-эпикграммы к гербам магнатов, а также городов княжеств, получивших Магдебургское право, включённые в соответствующие издания, являются одними из первых ренессансных и борочных белорусских литературных источников, содержащих сведения о ценных предметах. Наиболее известны в этом ключе тексты, подготовленные так называемым Несвижским литературным кружком (кружок возник во второй половине XVI столетия под патронажем князей Радзивиллов ${ }^{10}$, а также знатного магнатского рода Сапегов в среде библиофилов и поэтов, издателей Великого Княжества Литовского). Данные издания увидели свет на рубеже XVI-XVII столетий преимуще-

\footnotetext{
8 Там же, с. 29.

9 Там же, с. 30-31.

10 I. Саверчанка, Старажытная паэзія Беларусі XVI-першая палова XVII cm., c. 40 .
} 
ственно в виленских типографиях Яна Карцана, Даниэля Ленчицкого, а также Левона и Лукаша Мамоничей ${ }^{11}$.

Приведём пример эпикграммы Левона Мамонича «На герб ясневельможного пана, его милости, пана Лео Сапеги, канъцльра найвышъшого Великого Князьства Литовского, перънавъского, могилевъского и прочых старосты»12, которая была опубликована в двух редакциях: «Треодь цв Һ̆тная» (1609) и «Книга Служебник... коштом и накладом... Леона Сапеги, канцлера Великого Князьства Литовского» (1617)13. Данная эпикграмма была написана с упоминанием ряда ценных предметов. В ней упомянуты: «крыж», «крест»- крест; «пострбл»стрела; «тры лелие» или «крыны»- три лилии; «меч»- меч и другие геральдические символы, имеющие в то время также статус весьма дорогостоящих предметов обихода:

Презацный сенаторе, знат из в бков давных

Тые ж ся найдовали и в продках твых славных,

Што зъ гербов познаваем? Крыж - знак побожности,

Рука зъ силным пострплом - знаком ест мужности.

Трыл лелие, розных цнот образ указують,

Которые до неба простый путь справують

И у людей еднають славу безъсмертную,

Вち̆ в бком на потомъств Һ пребывающую...

Смотры, якъ крыныл, ездець и стрела з рукою

Звезалися, стрела с крестом, крест теж з луною.

Тыи суть зобранья цнот, Великій Леоне,

Которыми продков ушляхь̆тили кролеве.

Умысл маеш въспанялы громить еретики,

Которым теж пль̆ниш всђ церкви противники.

В韮, меч креста держачи, цвите тобою,

Бо естесь зъ супостатами готов до бою ${ }^{14}$.

Данные ценные предметы могли себе позволить исключительно представители местной магнатерии (наиболее богатых и влиятельных аристократических семей, крупнейших землевладельцев), а также зажиточных горожан княжества эпохи Ренессанса, поскольку инкрустированные драгоценными камнями и металлами доспехи, мечи, стрелы, кресты наряду с (..) фламандским, немецким и английским сукном,

11 Там же, с. 41.

12 Там же, с. 213.

13 Там же, с. 213.

14 Там же, с. 213. 
голландским и вестфальским полотном... были настолько дорогими, что приобретать их могли только богатье землевладельцьи и зажиточные горожане ${ }^{15}$.

Как отмечает современный исследователь О. Полубяко, весьма популярный у магнатерии эпохи Ренессанса венгерский головной убор из бархата или сукна - «магерка» с перьевым плюмажем - оценивался на землях Беларуси того времени в «червонный угорский» 16 . Упомянутый «червонный» - это «золотой» («злоты») или «дукат»- золотая венгерская монета, приравненная по стоимости к местным 30 «грошам» $(1 / 2 \text { «копы грошей» })^{17}$. Для сравнения: бутыль хорошего французского или итальянского виноградного вина (такое вино в то время также являлось ценностью) стоил на землях ренессансной Беларуси 6 «грошей» $(1 / 5$ «копы грошей»). Под «грошем» имеется в виду серебряная монета весом 3,87 грамма, которая (...) в $X I V-X V$ веках... составила основу денежного хозяйства на нашей территории. Даже в XVI веке налоги и штрафы уплачивались именно этой монетой ${ }^{18}$. Для сравнения: мера земли того времени «воло́ка» (чуть более 20 гектаров) стоила в княжестве от 60 до 120 «грошей», что составляло от 10 до 20 «коп грошей» (поскольку 1 дукат - это 30 грошей, а 1 копа грошей - это 60 грошей ${ }^{19}$. Таким образом, сумму, эквивалентную стоимости 20 гектаров земли, можно было получить за 10-20 бутлей западноевропейского виноградного вина либо за 2-4 венгерских головных убора с перьевым плюмажем, ввозимых из-за границы для местной магнатерии. Неспроста ценные зарубежные предметы изображались на гербах магнатов Великого Княжества Литовского, а также часто упоминались в литературных памятниках княжества времён Ренессанса.

Данные ценные предметы на гербах и их описаниях подчёркивали элитарность местных магнатов и наиболее зажиточных горожан, их принципиальное отличие от основной массы населения княжества,

15 Экономика Беларуси. XVI столетие. Экономические связи с Западной и Восточной Европой // История Беларуси / Studfiles. net [Eliektronny resurs]. - Rezhym dostupu: https://studfiles.net/preview/5772828/page:12/. - Data dostupu: 23.07.2019.

16 О. Полубяко, Про деньги и цены в ВКЛ. Ru.delfi.lt [Eliektronny resurs]. - Rezhym dostupu: https://ru.delfi.lt/vkl/history/pro-dengi-i-ceny-v-vkl-horoshaya-korova-stoila-do -1-5-kop-svinya-12-groshej. d?id=61.785.297. - Data dostupu: 23.07.2019.

17 В. Рабцэвіч, Злотьц (польск. złoty), Мінск 1993, с. 277.

18 В. Кулецкий, История белорусских монет в десяти фактах. [online], https:// finance.tut.by/news497272.html, [доступ: 23.07.2019]].

19 О. Полубяко, Про деньги и ценьв в ВКЛ. Ru.delfi.lt [Eliektronny resurs]. - Rezhym dostupu: https://ru.delfi.lt/vkl/history/pro-dengi-i-ceny-v-vkl-horoshaya-korova-stoila-do -1-5-kop-svinya-12-groshej. d?id=61.785.297. - Data dostupu: 23.07.2019. 
а также право магнатерии и городских богатеев на особые привилегии. В целом, (...) повыченный интерес $\kappa$ генеалогическим и геральдическим исследованиям связан со стремлением установить генетическую связь ${ }^{20}$, связь современного поколения с предшествующими носителями определённых достижений и сопутствующих им привилегий, обладания материальными ценностями. В условиях гуманизма, толерантности и мирного сосуществования различных религий Великого Княжества Литовского эпохи Ренессанса дорогостоящие предметы искусства часто упоминались в литературе, имели неоспоримую ценность, что, к сожалению, изменилось в условиях последующей Контрреформации XVII века, в значительной степени расколовшей и общество Княжества, и его эстетические предпочтения.

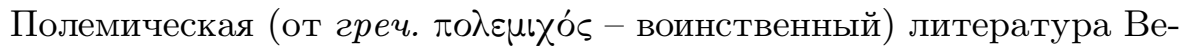
ликого Княжества Литовского, набравшая обороты при сопротивлении Контрреформации XVII столетия (под действие которой, кроме кальвинистов и лютеран, попали также православные церковные общины Беларуси и Украины) представлена целым рядом прозаических и стихотворных произведений. В них материальные ценности, приравненные к нехристианскому устремлению людей в направлении «роскошей и пыхи» ${ }^{21}-$ к удовлетворению необузданной тяги к роскоши и похоти, - как правило, противопоставляются духовным, а духовные ценности называются источниками жизни. Поэтому ряд материальных ценностей: «злато»- золото; «бисер»- жемчуг; «камения пресвҺ̆тлые» - драгоценные камни; «ризы» - богатый текстиль; а также «полаты» - роскошные интерьеры и архитектура часто упоминаются как обязательные атрибуты быта активных сторонников Контрреформации. В качестве последних фигурируют «Римляне»- католическое духовенство («О великій Риме, так прелести родишь и всякіи злости вже переродишь» ${ }^{22}$ ), а также магнаты-представители администрации Великого Княжества Литовского, которые (...) в иелях сохранения своих политических привилегий приняли католическое вероисповедание ${ }^{23}$. В результате Контрреформации объёмы доходов и финансовых операций магнатов-католиков резко выросли, став для большинства пра-

\footnotetext{
20 Мемориальная геральдика, Санкт-Петербург 2010, с. 5.

21 I. Саверчанка, Старажытная паэзія Беларусі XVI- першая палова XVII cm., c. 203.

22 Там же, с. 183.

23 Гісторыя беларускай дакастрычнічкай літаратуры. 3 старажытных часой да канца XVIII ст 1, пад рэд. В. Барысенкі, Мінск 1969, т. I, с. 7.
} 
вославного населения Княжества недостижимыми. Рождённый на Новогрудчине писатель-мемуарист Самуил Маскевич приводит в своём произведении «Diariusz» сведения о свадьбе наследника магнатского рода Глебовичей с княгиней Вишневецкой 1 февраля 1607 года, где приданное невесты составило «30000 золотых» 24 - либо 30000 дукатов, - цену примерно 300000 гектаров земли. Естественно, что такой уровень роскоши местных магнатов, которые своим согласием с противниками протестантизма и православия (...) ставили под реальную угрозу дальнейшее самостоятельное существование белорусского и украинского народов» ${ }^{25}$, закономерно вызывал осуждение православных литераторов-полемистов.

Приведём примеры противопоставления материальных и духовных ценностей в праздничных и обличительных стихотворениях, датированных рубежом XVI-XVII столетий из «Киево-Михайловского сборника». Сборник хранили в библиотеке Михайловского Златоверхого монастыря, одной из наиболее известных киевских обителей. Ее собор, основанный в XII веке, был первым храмом с золочёным верхом у восточных славян. Неизвестный автор стихотворения «Достойность чистоты» писал:

Не злато и бисер ниже многоцбнны, камений пресвптльх и ризы измънны.

Иже бо преходни паче же и тленни и цЊною своею бывають куплени.

Но благодать духа - источник живота, и разноличная Божия доброта ${ }^{26}$.

Сходные мысли высказывал неизвестный автор стихотворения «Достойность дҺ̆вства»:

Ибо временная видимого т Б̈ла, аще бы вышшую уроду имъ̆ла,

Красот䒓 душевной зровнати не може, иже увянути въ в бки не може.

По сем же дарует Ангельскую славу и одежить в ризу нетльниия нову.

Аще бо честни суть камыки въ златп, и людские роды кохаються в цноть̆,

24 Pamiętniki Samuela Maskiewicza, Wilno 1838, s. 22.

25 Гісторыля беларускай дакастрычнічкай літаратурь, т. 1, с. 271.

26 I. Саверчанка, Старажытная паэзія Беларусі XVI-першая палова XVII cm., c. 201 . 


\section{Многоцънны бисери царие мъъвают, дары любезными собъ посылают и свои полатьл св Һ̈тьло украшают 27 .}

Постоянно упоминаемое в памятниках белорусской литературы «злато»- это прежде всего золотые монеты, которые местные торговцы XV-XVII веков в духе своего времени успешно пускали в оборот. Княжество в XVII веке ещё представляло собой полиэтничное сообщество различных вероисповеданий, связанное с рядом ценных предметов, не всегда характерных для православного культового искусства. Поэтому привлекали внимание православных литераторов-полемистов определённые музыкальные инструменты: «органы»-костёльный орган; «трубы»- местная волынка-дуда; распространённые в то время на территории Великого Княжества Литовского. Вот фрагмент текста неизвестного автора «Крещеніе без мира у римлян» из «Загоровского сборника» начала XVII века:

Нынち вже Римляне письмо преслушали и набоженства их ново позмышляли.

Вже бо жидовствуют съ своими органь, любо плясальницы въ Бога поруганы.

Господь не требуетъ пищалей и шума, иже тщеславніи воплют без ума.

О мірская, будто Богу догожаешь и умиленіе зъ людей выганяешь.

Гудут бо трубами, якъ смоки рыкают, гд⿱⺊口 Божіи ангели приступу не мают ${ }^{28}$.

Другие музыкальные инструменты, известные в то время (скрипка, цимбалы, гусли, варган, фуяра ${ }^{29}$ ), обличителей инструментальной музыки в храме не раздражали. Видимо, искусство исполнительства на органе и дуде было неприятно поэту своим акустическим воздействием, а также моделированием определённого мировосприятия, производимым характерным этим музыкальным инструментам, так называемым бурдонированием - низкими мощными басующими нотами, которые православный автор стиха сравнивает с рычанием «смока» - с рычанием дракона.

27 Там же, с. 201.

28 Там же, с. 174.

29 Гісторыя беларускай дакастрычнічкай літаратуры, т. 1, с. 413. 
Таким образом, в известных памятниках давней белорусской литературы описываются следующие ценные предметы: монеты из золота и серебра, изделия из жемчуга и драгоценных камней, инкрустированные предметы культа, оружие, гербы, антикварные рукописи, музыкальные инструменты, геральдика с редкими экзотическими растениями и животными, привозные ткани и роскошные палаты, выступая символами красоты и отражая эстетические идеалы эпох Ренессанса и раннего Барокко.

\section{I T E R A T UR A}

Barvenava G., Tèkstyl' sârèdnâvečča na zemlâh Belarusì, rèd. Ì. Smâân, L. Spìrydonava; BDUKM, Mìnsk 2008 [Барвенава Г., Тэкстыльь Сярэднявечча на землях Беларусі, рэд. І. Смяян, Л. Спірыдонава; БДУКМ, Мінск 2008].

Èkonomika Belarusi. XVI stoletie. Èkonomičeskie svâzi s Zapadnoj i Vostočnoj Evropoj, [v:] Istoriâ Belarusi, [online], https://studfiles.net/preview/5772828 /page:12/, [dostup: 23.07.2019] [Экономика Беларуси. XVI столетие. Экономические связи с Западной и Восточной Европой, [в:] История Беларуси, [online], https://studfiles.net/preview/5772828/page:12/, [доступ: 23.07.2019]].

Gistoryâ belaruskaj dakastryčnickaj litaratury, t. 1. Z staražytnyh časoǔ da kanca XVIII st., rèd. V. Barysenka, Minsk 1977 [Гісторыля беларускай дакастрычнічкай літаратуры, т. 1. 3 старажытных часоў да канца XVIII cm., рэд. В. Барысенка, Мінск 1977].

Gončar M., Ėvolûciâ torgovyh otnošenij v VKL v XV-XVI vekah, [y:] Belarus'v sovremennom mire: materialy $V$ Meždunar. nauč. konf. studentov, aspirantov $i$ molodyh učenyh, red. V. Kirienko, Gomel' 2012 [Гончар М., Эволюиия торговых отношений в ВКЛ в XV-XVI веках, [y:] Беларусь в современном мире: материаль $V$ Междунар. науч. конф. студентов, аспирантов и молодых ученых, ред. В. Кириенко, Гомель 2012].

Gusoǔskì M., Pesnâ pra zubra / Carmen de statura feritate ac venatione bisontis / Pesn' o moũi, dikosti zubra i ohote na nego, per. z lac. movy Â. Parèckaga, Â. Semâžona, Mìnsk 1980 [Гусоўскі М., Песня пра зубра / Carmen de statura feritate ac venatione bisontis / Песнь о мощи, дикости зубра и охоте на него, пер. $з$ лац. мовы Я. Парэцкага, Я. Семяжона, Мінск 1980].

Hrèstamatyâ pa staražytnaj belaruskaj litaratury, sklad A. Koršunaǔ, rèd. İ. Âromìn, Mìnsk 1959 [Хрэстаматыля па старажытнай беларускай літаратуры, склад А. Коршунаў, рэд. І. Яромін, Мінск 1959].

Kuleckij V., Istoriâ belorusskih monet $v$ desâti faktah, [online] https://finance.tut. by/news497272.html, [dostup: 23.07.2019] [Кулецкий В., История белорусских монет в десяти фактах, [online], https://finance.tut.by/news497272 .html, [доступ: 23.07.2019]]. 
Lebâdzevič Dz., Staražytnâa belaruskaâ litaratura ì antyčnyâ tradycyì, [y:] Vzaimodejstvie literatur $v$ mirovom literaturnym processe(problemy teoretičeskoj $i$ istoričeskoj poètiki): Materialy meždunarodnoj naučnoj konferencii, red. Т. Avtuhovič, Grodno 1998, с̌. 1 [Лебядзевіч Дз., Старажытная беларуская літаратура і антыцныля традыцыі, [у:] Взаимодействие литератур в мировом литературным прочессе (проблемь теоретической и исторической поэтики): Материаль международной научной конферениии, ред. Т. Автухович, Гродно 1998, ч. 1].

Memorial'nâa geral'dika. Kollekciâ dvorânskih gerbov v sobranii Gosudarstvennogo muzeâ gorodskoj skul'ptury. Al'bom, sost. Ü. Pirûtko, A. Alekseev, Sankt-Peterburg 2010 [Мемориальная геральдика. Коллекиия дворянских гербов в собрании Государственного музея городской скульптуры. Альбом, сост. Ю. Пирютко, А. Алексеев, Санкт-Петербург 2010].

Pamiętniki Samuela Maskiewicza: początek swój biorą od roku 1594 w lata po sobie idące, nakładem i drukiem Teofila Glücksberga, Wilno 1838.

Polubâko O., Pro den'gi $i$ ceny v VKL, [online], https://ru.delfi.lt/vkl/history/prodengi-i-ceny-v-vkl-horoshaya-korova-stoila-do-1-5-kop-svinya-12-groshej.d? id=61785297, [dostup: 23.07.2019] [Полубяко О., Про деньги и иеньь в ВKЛ, [online], https://ru.delfi.lt/vkl/history/pro-dengi-i-ceny-v-vkl-horo shaya-korova-stoila-do-1-5-kop-svinya-12-groshej.d?id=61785297, [доступ: 23.07.2019]].

Rabcèvič V., Zloty (pol'sk. złoty), [u:] Arhealogiâì numizmatyka Belarusì: Ėncyklapedyâa, rèd. V. Getaǔ, Mìnsk 1993 [Рабцэвіч В., Злоть (nольск. złoty), [у:] Археалогія і нумізматыка Беларусі: Эниыклапедыля, рэд. В. Гетаў, Мінск 1993].

Saverčanka Ì., Staražytnâa paèzîa Belarusi XVI - peršâ̂a palova XVII st., rèd. A. Mal'dzìs, Mìnsk 1992 [Саверчанка I., Старажытная паэзія Беларусі XVI - першая палова XVII cm., рэд. А. Мальдзіс, Мінск 1992].

\section{S U M M A R Y}

\section{VALUABLE OBJECTS IN ANCIENT BELARUSIAN LITERATURE}

The article describes and analyzes an artistic context of valuable objects in famous texts of ancient Belarusian literature (16th century - the first half of the 17 th century) from the perspective of art studies and antiquarian practice. According to the author valuable objects in famous books of ancient Belarusian literature comprise gold and silver coins, pearl and precious stones, inlaid cult objects and weapons, exotic plants and animals, antiquarian books, coats of arms, musical instruments, imported fabrics and luxurious interiors. In the artistic context all above-mentioned objects are symbols of beauty ideals and diversity of the Renaissance and early Baroque in Europe.

Key words: valuable objects, art studies, antiquarian practice, ancient Belarusian literature, Renaissance, early Baroque. 